\title{
Perbedaan persepsi bimbingan akademik mahasiswa pada sebuah perguruan tinggi swasta di Indonesia
}

\author{
Sherlywati Sherlywati* \\ Universitas Kristen Maranatha \\ Jl. Prof. Drg. Surya Sumantri no. 65, 40164, Indonesia \\ sherlywati@eco.maranatha.edu \\ Imelda Junita \\ Universitas Kristen Maranatha \\ Jl. Prof. Drg. Surya Sumantri no. 65, 40164, Indonesia \\ imelda.junita@eco.maranatha.edu \\ Fanny Kristine \\ Universitas Kristen Maranatha \\ Jl. Prof. Drg. Surya Sumantri no. 65, 40164, Indonesia \\ fanny.kristine@eco.maranatha.edu \\ Elhaq Wisamtamma \\ Universitas Kristen Maranatha \\ Jl. Prof. Drg. Surya Sumantri no. 65, 40164, Indonesia \\ elhaqwm@gmail.com \\ *Penulis Korespondensi
}

Submitted: Nov 18, 2020; Reviewed: Dec 09, 2020; Accepted: Mar 01, 2021

\begin{abstract}
This research is about academic advising in bachelor degree of management department in a private university in Bandung City. There are two style of academic advising, prescriptive and developmental academic advising. The result showed developmental academic advising is covered in that department. In this research, the differences in perceptions of academic advising were tested based on gender, origin area of residence, age, year of study, intensity, and frequency of academic advising. The main objective of this research is to provide an evaluation of academic advising process based on academic demographic of respondents. The tests of differences were carried out by using Anova Test and U Mann Whitney Test on 302 samples of respondents. The results showed that there are differences in perceptions of academic advising based on ages, year of study, and frequency of academic advising. Meanwhile, some of variable such as gender, origin area of residence, and time intensity of academic advising, there were no differences in their perceptions. From the research results, the department can redesign the academic advising system which is suited to students to make academic advising becomes one of excellent academic achievement tool.
\end{abstract}

Keywords: academic advising, anova, developmental, differences test, prescriptive, u-mann whitney

Abstrak: Penelitian ini tentang bimbingan akademik di program studi sarjana manajemen pada sebuah perguruan tinggi swasta di Kota Bandung. Ada dua gaya bimbingan akademik, yaitu gaya preskriptif dan developmental. Hasil menunjukkan gaya bimbingan akademik di program studi 
tersebut adalah gaya developmental. Dalam penelitian ini, dilakukan uji perbedaan persepsi bimbingan akademik berdasarkan gender, asal daerah tempat tinggal, usia, angkatan kuliah, intensitas, dan frekuensi waktu bimbingan akademik. Tujuan utama penelitian adalah memberikan suatu evaluasi terhadap proses bimbingan akademik berdasarkan faktor demografis akademik responden. Uji beda dilakukan dengan uji Anova dan U Mann Whitney terhadap 302 orang sampel responden. Hasil-hasil menunjukkan bahwa terdapat perbedaan persepsi bimbingan akademik berdasarkan usia, angkatan kuliah, dan frekuensi bimbingan akademik. Sementara, beberapa variabel seperti gender, asal tempat tinggal, dan intensitas waktu bimbingan akademik, tidak terdapat perbedaan persepsi bimbingan akademik. Dari hasil-hasil penelitian, program studi dapat mendesain ulang sistem bimbingan akademik yang paling sesuai dengan mahasiswa agar bimbingan akademik dapat menjadi salah satu alat pencapaian akademik yang baik.

Kata kunci: anova; bimbingan akademik; developmental; preskriptif; u-mann whitney; uji beda

\section{PENDAHULUAN}

Bimbingan akademik sangat krusial dalam membentuk pengalaman dan keterlibatan mahasiswa di sebuah perguruan tinggi (Ayon, 2015). Perbedaan sistem akademik di sekolah menengah tingkat atas dengan perguruan tinggi membutuhkan peran bimbingan akademik. Perubahan pola belajar di perguruan tinggi menuntut mahasiswa memiliki kedewasaan dalam membuat keputusan dalam hal akademik. Bimbingan akademik akan mengarahkan mahasiswa untuk belajar mengambil keputusan selama menekuni perkuliahan. Topik penelitian bimbingan akademik menjadi salah satu topik yang menarik perhatian para peneliti bidang pendidikan. Banyak peneliti menekankan dampak dari pemberian nasihat akademik pada retensi mahasiswa, keberhasilan akademis, dan kepuasan mahasiswa selama berkuliah.

Kepuasan akan bimbingan akademik akan meningkatkan rasa memiliki (sense of belonging) dan retensi siswa (Soria, 2012). Pemberian nasihat akademis akan berdampak pada faktor-faktor yang berkontribusi pada keberhasilan siswa dalam meenyelesaikan studi tepat waktu dan penerapan pengetahuan yang efektif tentang semua aspek akademik pada siswa (Young-Jones et al., 2013). Penelitian Hsu \& Bailey (2011) mempertegas bahwa bimbingan akademik akan menimbulkan kepuasan siswa yang berdampak pada retensi siswa dan membangun kegigihan siswa dalam beradaptasi dengan kehidupan kampus. Topik penelitian bimbingan akademik menjadi salah satu fondasi dalam menemukan desain bimbingan akademik yang paling efektif guna membangun suasana pembelajaran akademik yang kondusif (Winston, 1984).

Bimbingan akademik memfasilitasi mahasiswa dalam memahami arti dan tujuan pendidikan tinggi serta menumbuhkan intelektual dan pertumbuhan personal menuju kesuksesan akademik, karir yang diimpikan, serta pembelajaran yang kekal (Tobi-David et al., 2018). Proses bimbingan akademik adalah sebuah proses yang berkelanjutan, di dalamnya terdapat hubungan dinamis yang melibatkan penasihat akademis sebagai fasilitator dengan siswa sebagai penerima nasihat akademis untuk memenuhi kebutuhan dan aspirasi akademik siswa (Enduljee \& Michaud, 2014). Ayon (2015) memaparkan ada dua tipe bimbingan akademik yang umumnya terjadi di perguruan tinggi, yaitu prescriptive academic advising dan developmental academic advising.

Bimbingan akademik preskriptif berfokus pada hal-hal akademik formal serta proses komunikasi antara dosen dan mahasiswa wali yang mencerminkan kepedulian terhadap akademik mahasiswa semata (Tobi-David et al., 2018). Menurut Crookston (1994), bimbingan preskriptif adalah kegiatan yang berfokus pada program yang mana dosen wali memberikan informasi yang dibutuhkan dan memantau kemajuan akademik. Bimbingan preskriptif mengasumsikan bahwa setelah nasihat diberikan, maka tanggung jawab dosen wali sebagian besar sudah terpenuhi (Crookston, 1994). Selanjutnya, tergantung mahasiswa untuk memenuhi tanggung jawabnya dalam menjalankan proses akademik yang telah ditentukan. Bimbingan akademik preskriptif merupakan model pemberian nasihat yang ditandai hubungan hierarkis, aliran informasi, dan ide satu arah, yang mana mahasiswa sebagai penerima pasif (Lowenstein, 1999).

Bimbingan akademik tipe developmental merupakan proses bimbingan yang intensif yang mana mahasiswa dan dosen wali memiliki ukuran kesetaraan yang sama, dan keduanya berperan aktif dalam 
kegiatan bimbingan akademik (Crookston, 1994). Dalam proses bimbingan developmental, kedua pihak memahami bahwa nasihat yang diberikan merupakan sistem tanggung jawab bersama yang mana tujuan utamanya adalah membantu mahasiswa lebih bertanggung jawab atas keputusan dan tindakan yang dilakukan terkait sepanjang proses perkuliahan (Gordon \& Hebley, 2000). Selama proses bimbingan akademik developmental, kedua pihak mempromosikan hubungan kerja sama yang kolaboratif, mendorong keterlibatan, dan mendorong perkembangan. Hal ini memegang persepsi bahwa setiap mahasiswa adalah unik, dengan tingkat kesigapan akademik yang bervariasi, sosial, serta emosional yang berbeda-beda (Soria, 2012). Tujuan esensial dari proses bimbingan developmental adalah pemberian saran untuk membantu mengklarifikasi minat, keterampilan, sikap, dan nilai-nilai terkait pengalaman kuliah dan tujuan karir. Proses ini akan mengembangkan keterampilan hidup yang akan memfasilitasi kesuksesan, pengalaman pencapaian, dan mengembangkan tujuan dan arah karir masa depan (Crookston, 1994).

Salah satu perguruan tinggi swasta di Kota Bandung terdeteksi memiliki proses bimbingan akademik dengan gaya developmental pada program studi sarjana manajemen (Junita et al., 2020). Hasil penelitian menunjukkan bimbingan akademik dibangun berdasarkan hubungan interpersonal, bukan sekedar menjawab pertanyaan spesifik dan selalu melibatkan mahasiswa dalam membuat pertimbangan untuk mengambil keputusan akademiknya. Secara umum, mahasiswa puas $(72,58 \%)$ terhadap proses bimbingan akademik, 71,86\% mahasiswa menilai bahwa telah menerima informasi yang akurat mengenai mata kuliah, program, dan persyaratan yang dibutuhkan selama proses pembimbingan akademik; 69,86\% mahasiswa menilai bahwa tersedia cukup waktu bagi mereka untuk memenuhi tenggat waktu yang diminta terkait prosedur dan kebijakan universitas; $68,87 \%$ mahasiswa menilai bahwa mereka telah memeroleh bimbingan akademik yang memadai pada saat dibutuhkan; serta $71,85 \%$ mahasiswa menilai bahwa mereka memeroleh cukup waktu untuk melakukan proses pembimbingan akademik. Tipe bimbingan akademik yang terbangun di program studi sarjana manajemen perguruan tinggi swasta ini adalah bimbingan akademik developmental (Junita et al., 2020).

Hasil penelitian tersebut dilakukan secara deskriptif, dengan melihat pola umum persepsi bimbingan akademik yang terjadi secara nyata di sebuah program studi sarjana perguruan tinggi swasta di kota Bandung. Untuk dapat mengamati lebih seksama, guna melakukan evaluasi dan perbaikan terhadap proses bimbingan akademik, perlu diamati perbedaan persepsi bimbingan akademik secara demografi akademik mahasiswa. Walker et al. (2017) mengungkapkan bahwa banyak faktor yang menyebabkan bimbingan akademik dapat menjadi instrumen bermanfaat bagi kesuksesan akademik mahasiswa, salah satunya pembimbing yang meluangkan waktu cukup banyak kepada mahasiswa bimbingannya. Sementara, Tobi-David et al. (2018) memaparkan perbedaan sistem bimbingan akademik di perguruan tinggi swasta dan negeri, serta Enduljee \& Michaud (2014) memperlihatkan perbedaan tingkat kepuasan proses bimbingan akademik pada sebuah perguruan tinggi swasta. Penelitian mengenai perbedaan persepsi bimbingan akademik dapat dijadikan dasar untuk perbaikan desain dan proses bimbingan akademik dalam mendukung capaian akademik mahasiswa. Maka dari itu, penelitian ini mengangkat perbedaan persepsi bimbingan akademik berdasarkan faktor demografis akademik mahasiswa dalam rangka mengevaluasi sistem bimbingan akademik yang berlangsung saat ini.

Tujuan utama penelitian ini adalah melihat perbedaan persepsi bimbingan akademik berdasarkan faktor demografis akademik mahasiswa, dengan tujuan mengevaluasi desain bimbingan akademik yang saat ini dilaksanakan serta memberikan rekomendasi desain bimbingan akademik yang diperlukan berdasarkan hasil evaluasi perbedaan persepsi bimbingan akademik mahasiswa. Maka dari itu, pertanyaan utama penelitian ini adalah apakah terdapat perbedaan persepsi proses bimbingan akademik berdasarkan faktor demografi akademik pada suatu program studi sebagai unit pembelajaran terkecil dalam suatu perguruan tinggi swasta. Tujuan khusus dari penelitian perbedaan persepsi proses bimbingan akademik berdasarkan faktor demografi adalah memberikan evaluasi terhadap proses bimbingan akademik dalam mendesain proses bimbingan akademik yang lebih baik sesuai faktor demografi akademik mahasiswa. Tujuan dari penelitian ini juga menimbang bahwa bimbingan akademik sangat penting untuk dipahami oleh pengelola fakultas dan program studi dalam mengintervensi perkembangan akademik dan personal mahasiswa (Schwitzer et al., 1999). Adapun hipotesis penelitian ini adalah sebagai berikut:

$\mathrm{H}_{1}$ : Terdapat perbedaan persepsi bimbingan akademik berdasarkan gender 
$\mathrm{H}_{2}$ : Terdapat perbedaan persepsi bimbingan akademik berdasarkan asal daerah

$\mathrm{H}_{3}$ : Terdapat perbedaan persepsi bimbingan akademik berdasarkan usia

$\mathrm{H}_{4}$ : Terdapat perbedaan persepsi bimbingan akademik berdasarkan angkatan kuliah

$\mathrm{H}_{5}$ : Terdapat perbedaan persepsi bimbingan akademik berdasarkan intensitas waktu bimbingan akademik

$\mathrm{H}_{6}$ : Terdapat perbedaan persepsi bimbingan akademik berdasarkan frekuensi bimbingan akademik dalam satu tahun

\section{METODE}

\subsection{Instrumen penelitian}

Instrumen penelitian diadaptasikan dari kuesioner Academic Advising Inventory (AAI) yang awalnya dikembangkan oleh Winston \& Sandor (2002), dan salah satunya terdapat pada penelitian Al-Omari \& Khasawneh (2014). AAI adalah kuesioner yang mengevaluasi tingkat preskriptif atau developmental bimbingan akademik yang dirasakan oleh siswa dan kepuasan siswa terhadap bimbingan akademik yang diterimanya (Al-Omari \& Khasawneh, 2014). Kuesioner AAI terdiri dari empat bagian (Winston, 1984). Bagian pertama kuesioner berisi informasi karakteristik demografis siswa. Bagian kedua kuesioner memberikan gambaran pendekatan gaya bimbingan akademik, terdiri dari tiga belas ekspresi untuk menilai sifat pendekatan bimbingan akademik berdasarkan pengalaman siswa dengan pembimbing mereka. Setiap pasangan ekspresi mencerminkan kontinum delapan poin antara dua gaya bimbingan akademik yang kontras, antara preskriptif dengan developmental. Bagian ketiga menyajikan informasi tentang topik yang dibahas selama sesi konsultasi bimbingan akademik. Kategori topik termasuk pertumbuhan pribadi dan hubungan interpersonal, kebijakan kelembagaan, serta rencana studi dan teknis pendaftaran. Penilaian bagian ketiga kuesioner dengan mentabulasikan frekuensi masing-masing respon dengan kisaran nilai nol sampai empat. Bagian keempat pada kuesioner terdiri dari lima item yang mengukur kepuasan siswa dengan pengalaman menasihati akademis mahasiswa. Mahasiswa menilai setiap item dengan skala Likert, mulai dari sangat tidak setuju (1) hingga sangat setuju (5). Skor rata-rata rendah menyiratkan ketidakpuasan atas bimbingan akademik, demikian sebaliknya untuk skor rata-rata tinggi menyiratkan kepuasan yang lebih besar dengan bimbingan akademik.

\subsection{Pengujian dan pengolahan data}

Instrumen penelitian AAI versi original diketahui memiliki validitas dan reliabilitas konstruk yang substansial, berdasarkan studi yang dirilis oleh Winston (1984). Reliabilitas AAI ditetapkan menggunakan prosedur alpha Cronbach, dengan koefisien alpha untuk level preskriptif dan developmental diperoleh sebesar 0,78. Hal ini menunjukkan bahwa AAI relatif homogen dan stabil untuk digunakan pada berbagai kelompok siswa (Harris, 2018). Dalam uji validitas, hasilnya menunjukkan perbedaan yang signifikan secara statistik pada keseluruhan skor AAI yang digunakan untuk mengukur apakah kelompok siswa menerima bimbingan developmental atau preskriptif (Harris, 2018). Secara keseluruhan, kuesioner menunjukkan validitas struktural dan konsistensi internal yang baik. Untuk meyakinkan validitas dan reliabilitas instrumen penelitian, kedua uji tersebut tetap dilakukan pada penelitian ini.

Pengujian perbedaaan persepsi bimbingan akademik berdasarkan variabel faktor demografis akademik gender dan usia mahasiswa dilakukan dengan uji statistika non parametrik, dengan menggunakan alat uji U-Mann Whitney untuk pengujian dua sampel bebas (Sekaran \& Bougie, 2016). Uji U-Mann Whitney ditentukan dengan terlebih dahulu melakukan uji normalitas data. Sementara, pengujian perbedaan persepsi bimbingan akademik berdasarkan variabel asal daerah tempat tinggal, angkatan kuliah, intensitas waktu bimbingan, dan frekuensi bimbingan akademik selama satu semester, dilakukan menggunakan uji one-way analysis of variance (Anova). Uji Anova dapat dilakukan jika memiliki varians yang sama. Pengujian varians dilakukan dengan test of homogeneity of variances (Ghozali, 2013). 


\subsection{Populasi dan sampel penelitian}

Populasi dalam penelitian ini merupakan mahasiswa program studi sarjana manajemen pada sebuah perguruan tinggi swasta di Kota Bandung, sebanyak 1065 orang mahasiswa aktif pada semester Genap 2019/2020. Sampel penelitian diambil menggunakan teknik Slovin, sehingga minimal jumlah sampel adalah 290 orang responden, dengan rumus Slovin berikut:

$n=\frac{N}{N \cdot d^{2}+1}$

Jumlah kuesioner yang disebar sebanyak 320 kuesioner, dan didapati kuesioner yang diisi dengan lengkap dan dapat diolah adalah sebanyak 302 kuesioner AAI, lebih dari minimal jumlah sampel berdasarkan Slovin sebanyak 290 orang responden. Kuesioner disajikan secara online dengan pertimbangan lebih efisien dan efektif dibandingkan kuesioner berbasis kertas, serta akses yang lebih akurat dan lebih terstruktur pada populasi yang cukup besar (Ward et al., 2012).

Penelitian ini bertujuan untuk menguji hipotesis penelitian perbedaan bimbingan akademik berdasarkan faktor demografis akademik responden. Pemilihan sampel penelitian dilakukan berdasarkan pada kriteria tertentu (purposive sampling). Kriteria yang digunakan berdasarkan pertimbangan sebagai mahasiswa/ i aktif dan memiliki pengalaman melaksanakan proses bimbingan akademik minimal selama satu tahun ajaran yang diadakan oleh program studi sarjana manajemen.

\section{HASIL DAN PEMBAHASAN}

\subsection{Uji validitas dan reliabilitas}

Instrumen penelitian dilakukan uji validitas dengan Pearson correlation dan uji realibilitas dengan Cronbach's alpha pada bagian kedua sampai keempat kuesioner. Bagian pertama merupakan instrumen untuk mendapatkan karakteristik demografis responden. Bagian kedua merupakan instrumen untuk mengetahui pendekatan bimbingan akademik (Academic Advising Aproach/ AAA). Kuesioner AAA terdiri dari tiga belas item pertanyaan. Bagian ketiga adalah instrumen yang menyajikan informasi tentang topik yang dibahas selama sesi bimbingan akademik (Academic Advising Session/ AAS), yang terdiri dari dua puluh delapan item pertanyaan. Bagian keempat merupakan instrumen untuk mengukur kepuasan dalam menjalankan bimbingan akademik (Satisfaction Academic Advising/ SAA) yang terdiri dari lima item pertanyaan.

Tabel 1. Hasil uji validitas kuesioner AAA

\begin{tabular}{lcl}
\hline Item & Pearson correlation & Status \\
\hline AAA1 & 0,806 & Valid \\
AAA2 & 0,760 & Valid \\
AAA3 & 0,750 & Valid \\
AAA4 & 0,803 & Valid \\
AAA5 & 0,633 & Valid \\
AAA6 & 0,721 & Valid \\
AAA7 & 0,638 & Valid \\
AAA8 & 0,789 & Valid \\
AAA9 & 0,734 & Valid \\
AAA10 & 0,700 & Valid \\
AAA11 & 0,744 & Valid \\
AAA12 & 0,797 & Valid \\
AAA13 & 0,812 & Valid \\
\hline SuA
\end{tabular}

Sumber: Hasil pengolahan SPSS (2020) 
Jurnal Manajemen Maranatha a Vol. 20 Nomor 2, Mei (2021)

Tabel 2. Hasil uji validitas kuesioner AAS

\begin{tabular}{lcc}
\hline Item & Pearson correlation & Status \\
\hline AAS1 & 0,596 & Valid \\
AAS2 & 0,241 & Tidak Valid \\
AAS3 & 0,330 & Valid \\
AAS4 & 0,693 & Valid \\
AAS5 & 0,712 & Valid \\
AAS6 & 0,741 & Valid \\
AAS7 & 0,697 & Valid \\
AAS8 & 0,567 & Valid \\
AAS9 & 0,643 & Valid \\
AAS10 & 0,807 & Valid \\
AAS11 & 0,635 & Valid \\
AAS12 & 0,636 & Valid \\
AAS13 & 0,718 & Valid \\
AAS14 & 0,728 & Valid \\
AAS15 & 0,687 & Valid \\
AAS16 & 0,769 & Valid \\
AAS17 & 0,750 & Valid \\
AAS18 & 0,777 & Valid \\
AAS19 & 0,772 & Valid \\
AAS20 & 0,680 & Valid \\
AAS21 & 0,655 & Valid \\
AAS22 & 0,708 & Valid \\
AAS23 & 0,782 & Valid \\
AAS24 & 0,781 & Valid \\
AAS25 & 0,704 & Valid \\
AAS26 & 0,759 & Valid \\
AAS27 & 0,732 & Valid \\
AAS28 & 0,747 & Valid \\
\hline S4 &
\end{tabular}

Sumber: Hasil pengolahan SPSS (2020)

Tabel 3. Hasil uji validitas kuesioner SAA

\begin{tabular}{lcl}
\hline Item & Pearson correlation & Status \\
\hline SAA1 & 0,912 & Valid \\
SAA2 & 0,874 & Valid \\
SAA3 & 0,850 & Valid \\
SAA4 & 0,879 & Valid \\
SAA5 & 0,850 & Valid \\
\hline
\end{tabular}

Sumber: Hasil pengolahan SPSS (2020)

Berdasarkan hasil uji validitas, terlihat bahwa seluruh item pertanyaan pada kuesioner bagian AAA, AAS, dan SAA menunjukkan hasil yang signifikan, yaitu nilai Pearson correlation $>0,3$, kecuali satu item pertanyaan AAS2. Jadi seluruh item AAA, AAS, dan SAA adalah valid kecuali item AAS2. AAS merupakan bagian kuesioner bimbingan akademik untuk menilai topik yang dibahas pada sesi bimbingan akademik. Item kedua dari AAS bertanya mengenai "Seberapa sering Anda menandatangani formulir perwalian?". Item pertanyaan ini tidak valid dan selanjutnya dikeluarkan dari pengolahan dan analisis data.

Tabel 4. Hasil uji reliabilitas

\begin{tabular}{lcl}
\hline Indikator & Cronbach's alpha & Status \\
\hline AAA & 0,934 & Reliabel \\
AAS & 0,959 & Reliabel \\
SAA & 0,922 & Reliabel \\
\hline
\end{tabular}

Sumber: Hasil pengolahan SPSS (2020) 
Berdasarkan hasil uji validitas, seluruh item yang telah dinyatakan valid, juga dinyatakan reliable. Adapun batasan kriteria reliabilitas dengan Cronbach's alpha adalah 0,60, dan seluruh kelompok pertanyaan pada kuesioner Academic Advising Inventory memenuhi kriteria, yaitu memiliki nilai Cronbach's alpha lebih besar atau sama dengan 0,60.

\subsection{Perbedaan persepsi bimbingan akademik berdasarkan gender}

Responden penelitian sejumlah 302 orang mahasiswa terdiri dari 53,64\% laki-laki dan 46,36\% perempuan. Uji perbedaan persepsi bimbingan akademik berdasarkan gender dilakukan dengan uji statistika non-parametrik, dengan menggunakan alat uji U-Mann Whitney untuk pengujian dua sampel bebas (Sekaran \& Bougie, 2016). Pengujian didahulukan dengan uji normalitas data dengan hasil uji normalitas data terlampir pada Tabel 5 .

Tabel 5. Hasil uji normalitas data gender

\begin{tabular}{llr}
\hline \multicolumn{2}{c}{ One-Sample Kolmogorov-Smirnov Test } \\
\hline $\mathrm{N}$ & & Persepsi \\
\hline Normal Parameters ${ }^{\mathrm{a}, \mathrm{b}}$ & Mean & 302 \\
& Std. Deviation & 1,58995 \\
Most Extreme & Absolute & 0,091 \\
Differences & Positive & 0,045 \\
Kolmogorov-Smirnov $Z$ & Negative & $-0,091$ \\
Asymp. Sig. (2-tailed) & & 1,576 \\
a. Test distibuton is Norm & 0,014 \\
\hline
\end{tabular}

a. Test distribution is Normal.

b. Calculated from data.

Sumber: Hasil pengolahan SPSS (2020)

Berdasarkan hasil uji data normalitas, diketahui nilai asymp. sig. yang dihasilkan adalah $0,014<$ alpha 0,05 , maka data tidak berdistribusi normal. Karena tidak berdistribusi normal, maka alat uji beda yang digunakan adalah U-Mann Whitney test. Pada Tabel 6 disajikan hasil uji perbedaan persepsi berdasarkan gender menggunakan uji U-Mann Whitney.

Tabel 6. Hasil uji beda u-mann whitney test berdasarkan gender

\begin{tabular}{lr}
\hline & \multicolumn{1}{c}{ Persepsi } \\
\hline Mann-Whitney U & 10043,000 \\
Wilcoxon W & 19913,000 \\
Z & $-1,714$ \\
Asymp. Sig. (2-tailed) & 0,086 \\
\hline
\end{tabular}

a. grouping variable: Gender

Sumber: Hasil pengolahan SPSS (2020)

Berdasarkan hasil pengujian U-Mann Whitney Test, diketahui nilai asymp. sig yang diperoleh adalah 0,086. Nilai asymp. sig lebih besar dari alpha yang digunakan sebesar 0,05, maka dapat disimpulkan bahwa hipotesis penelitian $\left(\mathrm{H}_{1}\right)$ ditolak, yang mana tidak terdapat perbedaan persepsi bimbingan akademik berdasarkan gender pada proses bimbingan akademik di program studi sarjana yang dijadikan tempat penelitian. Berbeda dengan hasil penelitian yang dilakukan oleh Kato \& Song (2018), yang mana menemukan efek gender dalam hubungan pembimbing akademik pada tiga hasil utama yaitu retensi, nilai akademik, dan karir setelah kelulusan. Kesesuaian gender antara pembimbing akademik dan mahasiswa dapat menjadi pertimbangan dalam mendesain sistem bimbingan akademik di perguruan tinggi.

\subsection{Perbedaan persepsi bimbingan akademik berdasarkan asal daerah tempat tinggal}

Asal daerah tempat tinggal responden dibedakan menjadi tiga kategori, yaitu asal kota Bandung, asal luar kota Bandung di Pulau Jawa, dan asal luar Pulau Jawa. Dari total 302 orang responden, mayoritas 
responden berasal dari kota Bandung sebanyak 56,95\%, berasal dari luar kota Bandung namun masih di Pulau Jawa sebanyak 20,86\%, dan yang berasal dari luar Pulau Jawa sebanyak 22,19\%. Dengan tiga kategori asal daerah responden, pengujian perbedaan persepsi bimbingan akademik dilakukan dengan menggunakan alat uji one-way analysis of variance (Anova). Uji anova dapat dilakukan jika memiliki varians yang sama. Pengujian varians dilakukan dengan test of homogeneity of variances (Ghozali, 2013), dan Tabel 7 berikut merupakan hasil pengujian varians untuk variabel asal daerah responden.

Tabel 7. Hasil uji varians variabel asal daerah tempat tinggal

Test of homogeneity of variances

Persepsi

\begin{tabular}{cccc}
\hline Levene Statistic & df1 & df2 & Sig. \\
\hline 1,555 & 2 & 299 & 0,213 \\
\hline
\end{tabular}

Sumber: Hasil pengolahan SPSS (2020)

Berdasarkan hasil test of homogeneity of variances, nilai sig. sebesar 0,213 lebih besar dari alpha yang digunakan 0,05, maka disimpulkan varians kelompok penelitian memiliki varians yang sama dan asumsi Anova terpenuhi sehingga dapat lanjut ke pengujian Anova. Tabel 8 menyajikan hasil pengujian Anova untuk variabel asal daerah tempat tinggal.

Tabel 8. Hasil uji beda anova berdasarkan asal daerah tempat tinggal

\begin{tabular}{lccccc}
\hline \multicolumn{7}{c}{ ANOVA } \\
\hline Persepsi & Sum of Squares & df & Mean Square & F & Sig. \\
\hline Between Groups & 6,036 & 2 & 3,018 & 1,195 & 0,304 \\
Within Groups & 754,873 & 299 & 2,525 & & \\
Total & 760,910 & 301 & & & \\
\hline Suth:
\end{tabular}

Sumber: Hasil pengolahan SPSS (2020)

Berdasarkan hasil uji Anova, dapat dilihat ada tidaknya perbedaan dengan melihat nilai sig. yang diperoleh dibandingkan dengan tingkat kepercayaan yang digunakan. Pada variabel asal daerah tempat tinggal, nilai sig. sebesar 0,304 lebih besar dari alpha 0,05, sehingga hipotesis penelitian $\left(\mathrm{H}_{2}\right)$ ditolak yang mana artinya tidak terdapat perbedaan persepsi berdasarkan asal daerah tempat tinggal responden. Karena tidak ada perbedaan persepsi pada variabel asal daerah tempat tinggal, maka pengujian post hoc dalam uji Anova tidak dilakukan. Hal ini didukung oleh penelitian-penelitian bimbingan akademik lainnya yang tidak menunjukkan adanya perbedaan persepsi bimbingan akademik berdasarkan asal daerah tempat tinggal. Hal ini menunjukkan bahwa bimbingan akademik memiliki kesetaraan urgensi, baik bagi siswa yang berasal dari dalam kota, luar provinsi, atau bahkan luar pulau. Bimbingan akademik diperlukan sebagai salah satu instrumen bagi siswa dalam meraih kinerja akademik (Young-Jones et al., 2013).

\subsection{Perbedaan persepsi bimbingan akademik berdasarkan usia saat ini}

Kategori usia responden dibagi kedalam dua kategori, yaitu usia 18-22 tahun dan $>22$ tahun. Dari 302 orang responden, mayoritas berusia di rentang 18-22 tahun, yaitu sebanyak $88,08 \%$ dan selebihnya sebanyak $11,92 \%$ berusia di atas 22 tahun. Uji perbedaan persepsi berdasarkan usia dilakukan seperti analisis perbedaan persepsi berdasarkan gender karena memiliki dua kategori. Uji dilakukan menggunakan uji statistika non parametrik dengan alat uji U-Mann Whitney. Sebelum pengujian Mann Whitney dilakukan, terlebih dahulu dilakukan uji normalitas data. Tabel 9 berikut adalah hasil uji data normalitas berdasarkan variabel usia responden saat ini.

Tabel 9. Hasil uji normalitas data usia saat ini

\begin{tabular}{lcr}
\hline \multicolumn{2}{c}{ One-Sample Kolmogorov-Smirnov Test } \\
\hline $\mathrm{N}$ & Persepsi \\
\hline Normal Parameters ${ }^{\mathrm{a}, \mathrm{b}}$ & Mean & 302 \\
& 5,2950
\end{tabular}




\begin{tabular}{llr} 
& Std. Deviation & 1,58995 \\
Most Extreme & Absolute & 0,091 \\
Differences & Positive & 0,045 \\
Kolmogorov-Smirnov Z & Negative & $-0,091$ \\
Asymp. Sig. (2-tailed) & & 1,576 \\
\hline
\end{tabular}

a. Test distribution is Normal.

b. Calculated from data.

Sumber: Hasil pengolahan SPSS (2020)

Nilai asymp sig. menunjukkan angka 0,014, lebih kecil dari alpha yang digunakan sebesar 0,05, maka dapat disimpulkan bahwa data tidak berdistribusi normal. Karena data tidak berdistribusi normal, maka alat uji perbedaan persepsi bimbingan akademik yang akan digunakan adalah U-Mann Whitney Test. Tabel 10 berikut menyajikan hasil uji perbedaan persepsi berdasarkan usia dengan U-Mann Whitney Test.

Tabel 10. Hasil uji beda u-mann whitney test berdasarkan usia saat ini

\begin{tabular}{lr}
\hline \multicolumn{2}{c}{${\text { Test } \text { Statistics }^{\mathrm{a}}}^{\mathrm{c}}$ Persepsi } \\
\hline Mann-Whitney U & 3532,000 \\
Wilcoxon W & 39310,000 \\
Z & $-2,348$ \\
Asymp. Sig. (2-tailed) & 0,019 \\
\hline \multicolumn{2}{l}{ a. Grouping Variable: Usia } \\
\hline \multicolumn{2}{l}{ Sumber: Hasil pengolahan SPSS (2020) }
\end{tabular}

Berdasarkan hasil pengujian perbedaan persepsi bimbingan akademik berdasarkan usia responden saat ini, diketahui nilai asymp. sig. sebesar 0,019. Nilai asymp. sig. lebih kecil dari alpha yang digunakan (sebesar 0,05 ), maka dapat disimpulkan hipotesis penelitian $\left(\mathrm{H}_{3}\right)$ diterima, yang artinya terdapat perbedaan persepsi mahasiswa tentang bimbingan akademik berdasarkan usia saat ini. Usia menjadi salah satu faktor yang perlu dijadikan pertimbangan ketika menyusun strategi bimbingan akademik. Usia akan sejalan dengan angkatan kuliah mahasiswa. Angkatan kuliah awal merupakan usia yang rawan membutuhkan bimbingan akademik yang lebih intensif. Peralihan usia di kelas bangku sekolah ke perguruan tinggi merupakan masa genting siswa dalam menemukan gaya belajar yang lebih mandiri di perkuliahan (Junita et al., 2020). Temuan hasil penelitian perbedaan persepsi bimbingan akademik berdasarkan usia menunjukkan bahwa diperlukan bentuk bimbingan akademik yang khusus bagi mahasiswa di tahun pertama kuliahnya karena diindikasikan usia yang masih sangat belia yang merupakan peralihan dari usia sekola menuju usia berkuliah.

\subsection{Perbedaan persepsi bimbingan akademik berdasarkan angkatan kuliah}

Angkatan kuliah dari 302 orang responden yang terlibat dalam penelitian terdiri dari 40,8\% angkatan 2016, 25,9\% angkatan 2018, 18,8\% angkatan 2017, 8,7\% angkatan 2015, 3,6\% angkatan 2014, dan $2,3 \%$ angkatan 2013. Karena memiliki lebih dari dua kelompok kategori angkatan kuliah, pengujian perbedaan persepsi bimbingan akademik berdasarkan angkatan kuliah dilakukan dengan menggunakan Anova yang didahului dengan test of homogeneity of variances untuk melihat apakah memiliki varians yang sama. Hasil pengujian varians disajikan pada Tabel 11 berikut ini.

Tabel 11. Hasil uji varians variabel angkatan kuliah

\begin{tabular}{lccc}
\hline \multicolumn{2}{c}{ Test of homogeneity of variances } \\
\hline $\begin{array}{c}\text { Persepsi } \\
\text { Levene Statistic }\end{array}$ & df1 & df2 & Sig. \\
\hline 1,663 & 5 & 296 & 0,143 \\
\hline
\end{tabular}

Sumber: Hasil pengolahan SPSS (2020) 
Berdasarkan hasil test of homogeneity of variances, hasil uji nilai sig. adalah 0,143 , lebih besar daripada tingkat alpha yang digunakan yaitu 0,05; maka dapat disimpulkan bahwa varians kelompok penelitian memiliki varians yang sama sehingga asumsi Anova terpenuhi. Selanjutnya, uji perbedaan persepsi bimbingan akademik berdasarkan angakatan kuliah dapat dilakukan dengan alat uji Anova. Tabel 12 berikut menunjukkan hasil pengujian Anova berdasarkan angkatan kuliah.

Tabel 12. Hasil uji beda anova berdasarkan angkatan kuliah

\begin{tabular}{lccccc}
\hline \multicolumn{5}{c}{ ANOVA } \\
\hline Persepsi & Sum of Squares & df & Mean Square & F & Sig. \\
\hline Between Groups & 43,619 & 5 & 8,724 & 3,600 & 0,004 \\
Within Groups & 717,291 & 296 & 2,423 & & \\
Total & 760,910 & 301 & & & \\
\hline
\end{tabular}

Sumber: Hasil pengolahan SPSS (2020)

Hasil uji Anova menunjukkan nilai sig. sebesar 0,04 lebih kecil dari alpha yang digunakan sebesar 0,05 , sehingga hipotesis penelitian diterima $\left(\mathrm{H}_{4}\right)$. Kesimpulannya adalah terdapat perbedaan persepsi bimbingan akademik berdasarkan angkatan kuliah. Karena hasil uji Anova menunjukkan adanya perbedaan, maka pengujian selanjutnya adalah pengujian post hoc untuk melihat kelompok kategori mana yang memiliki perbedaan. Tabel 13 menunjukkan hasil uji post hoc test berdasarkan kategori angkatan kuliah.

Tabel 13. Hasil uji post hoc test berdasarkan angkatan kuliah

Multiple comparisons

Dependent Variable: Persepsi

Tukey HSD

\begin{tabular}{|c|c|c|c|c|c|c|}
\hline \multirow[t]{2}{*}{ (I) Angkatan } & \multirow[t]{2}{*}{ (J) Angkatan } & \multirow{2}{*}{$\begin{array}{c}\text { Mean } \\
\text { Difference (I-J) }\end{array}$} & \multirow{2}{*}{$\begin{array}{c}\text { Std. } \\
\text { Error }\end{array}$} & \multirow[t]{2}{*}{ Sig. } & \multicolumn{2}{|c|}{ 95\% Confidence Interval } \\
\hline & & & & & Lower Bound & Upper Bound \\
\hline \multirow{5}{*}{2013} & 2014 & $-0,01515$ & 0,79005 & 1,000 & $-2,2814$ & 2,2511 \\
\hline & 2015 & 1,54558 & 0,70259 & 0,241 & $-0,4698$ & 3,5610 \\
\hline & 2016 & 0,58092 & 0,65096 & 0,948 & $-1,2863$ & 2,4482 \\
\hline & 2017 & 1,06680 & 0,66813 & 0,601 & $-0,8497$ & 2,9833 \\
\hline & 2018 & 1,13940 & 0,65921 & 0,514 & $-0,7515$ & 3,0303 \\
\hline \multirow{5}{*}{2014} & 2013 & 0,01515 & 0,79005 & 1,000 & $-2,2511$ & 2,2814 \\
\hline & 2015 & 1,56074 & 0,55682 & 0,060 & $-0,0365$ & 3,1580 \\
\hline & 2016 & 0,59607 & 0,49006 & 0,829 & $-0,8097$ & 2,0018 \\
\hline & 2017 & 1,08195 & 0,51265 & 0,285 & $-0,3886$ & 2,5525 \\
\hline & 2018 & 1,15455 & 0,50097 & 0,195 & $-0,2825$ & 2,5916 \\
\hline \multirow{5}{*}{2015} & 2013 & $-1,54558$ & 0,70259 & 0,241 & $-3,5610$ & 0,4698 \\
\hline & 2014 & $-1,56074$ & 0,55682 & 0,060 & $-3,1580$ & 0,0365 \\
\hline & 2016 & $-0,96467 *$ & 0,33108 & 0,044 & $-1,9144$ & $-0,0150$ \\
\hline & 2017 & $-0,47878$ & 0,36368 & 0,776 & $-1,5220$ & 0,5644 \\
\hline & 2018 & $-0,40618$ & 0,34702 & 0,851 & $-1,4016$ & 0,5893 \\
\hline \multirow{5}{*}{2016} & 2013 & $-0,58092$ & 0,65096 & 0,948 & $-2,4482$ & 1,2863 \\
\hline & 2014 & $-0,59607$ & 0,49006 & 0,829 & $-2,0018$ & 0,8097 \\
\hline & 2015 & $0,96467 *$ & 0,33108 & 0,044 & 0,0150 & 1,9144 \\
\hline & 2017 & 0,48589 & 0,24975 & 0,377 & $-0,2305$ & 1,2023 \\
\hline & 2018 & 0,55849 & 0,22481 & 0,132 & $-0,0864$ & 1,2033 \\
\hline \multirow{5}{*}{2017} & 2013 & $-1,06680$ & 0,66813 & 0,601 & $-2,9833$ & 0,8497 \\
\hline & 2014 & $-1,08195$ & 0,51265 & 0,285 & $-2,5525$ & 0,3886 \\
\hline & 2015 & 0,47878 & 0,36368 & 0,776 & $-0,5644$ & 1,5220 \\
\hline & 2016 & $-0,48589$ & 0,24975 & 0,377 & $-1,2023$ & 0,2305 \\
\hline & 2018 & 0,07260 & 0,27053 & 1,000 & $-0,7034$ & 0,8486 \\
\hline \multirow{2}{*}{2018} & 2013 & $-1,13940$ & 0,65921 & 0,514 & $-3,0303$ & 0,7515 \\
\hline & 2014 & $-1,15455$ & 0,50097 & 0,195 & $-2,5916$ & 0,2825 \\
\hline
\end{tabular}




$\begin{array}{llllll}2015 & 0,40618 & 0,34702 & 0,851 & -0,5893 & 1,4016 \\ 2016 & -0,55849 & 0,22481 & 0,132 & -1,2033 & 0,0864 \\ 2017 & -0,07260 & 0,27053 & 1,000 & -0,8486 & 0,7034\end{array}$

*. The mean difference is significant at the 0,05 level.

Sumber: Hasil pengolahan SPSS (2020)

Tujuan pengujian post hoc test adalah menentukan apakah antar kelompok kategori memiliki perbedaan atau tidak dengan cara melihat tabel multiple comparison (Ghozali, 2013). Pada angkatan 2013 dengan 2014 memiliki nilai sig. sebesar 1,00 yang mana nilai lebih besar dari alpha 0,05, maka dapat disimpulkan bahwa tidak terdapat perbedaan persepsi bimbingan akademik angkatan 2013 dengan 2014. Demikian pula untuk angkatan lainnya, juga memiliki nilai sig. lebih besar dari alpha 0,05 , maka dapat disimpulkan tidak terdapat perbedaan persepsi bimbingan akademik antar angkatan. Kasus khusus untuk hasil pengujian post hoc test angkatan 2015 dengan 2016 memiliki nilai sig. 0,044 yang mana nilai lebih kecil dari alpha 0,05, maka dapat disimpulkan bahwa terdapat perbedaaan persepsi bimbingan akademik antara angkatan 2015 dan angkatan 2016.

Hasil pengujian perbedaan persepsi bimbingan akademik berdasarkan angkatan kuliah selaras dengan temuan perbedaan persepsi bimbingan akademik berdasarkan usia. Semakin menunjukkan usia yang matang untuk berkuliah, perbedaan persepsi bimbingan akademik semakin tidak muncul. Hal ini terlihat antara kelompok angkatan 2013 dan 2014 yang tidak memiliki perbedaan persepsi bimbingan akademik. Namun, terdapat perbedaan persepsi bimbingan akademik untuk angkatan 2015 dan 2016. Sesuai dengan penelitian Roessger et al. (2019) yang menemukan bahwa siswa yang lebih tua menggunakan layanan bimbingan akademik hanya pada tahun pertama, sama sepeti siswa yang lebih muda dalam rangka mengikuti prosedur akademik yang ditentukan oleh perguruan tinggi. Seiring bertambahnya usia siswa, mereka cenderung tidak berpartisipasi dalam pembinaan akademik. Temuan Roessger et al. (2019) ini mendukung asumsi teori belajar mandiri dan menyoroti bahwa tidak semua siswa berpartisipasi secara sama dalam pembimbingan akademik. Secara khusus, pendidik perlu merancang pengalaman menasihati akademik yang lebih mandiri daripada diarahkan secara administratif untuk memastikan keberhasilan akademik.

\subsection{Perbedaan persepsi bimbingan akademik berdasarkan intensitas waktu bimbingan akademik}

Kategori intensitas waktu bimbingan akademik dibagi menjadi empat kategori, yaitu kurang dari lima belas menit, 15-30 menit, 31-60 menit, dan lebih dari satu jam. Mayoritas responden melakukan bimbingan akademik selama 15-30 menit (sebanyak 57,95\%). Selanjutnya, mayoritas responden melakukan bimbingan akademik selama kurang dari 15 menit sebanyak 33,11\% responden. Hanya 0,66\% responden yang melakukan bimbingan akademik selama 31-60 menit. Pengujian perbedaan persepsi bimbingan akademik berdasarkan intensitas waktu bimbingan akademik memiliki lebih dari dua kategori dilakukan dengan uji Anova yang sebelumnya dilakukan uji varians dengan test homogeneity of variances.

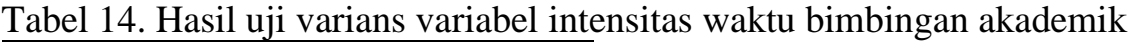

\begin{tabular}{lccc}
\hline \multicolumn{1}{l}{ Test of homogeneity of variances } \\
\hline \begin{tabular}{cccc} 
Persepsi \\
Levene Statistic & df1 & df2 & Sig. \\
\hline 3,713 & 3 & 298 & 0,012 \\
\hline
\end{tabular}
\end{tabular}

Sumber: Hasil pengolahan SPSS (2020)

Berdasarkan hasil test of homogeneity of variances, menunjukkan hasil uji nilai sig. 0,012, lebih kecil daripada alpha yang digunakan sebesar 0,05, maka dapat disimpulkan bahwa varians kelompok penelitian memiliki varians yang berbeda dan asumsi Anova tidak terpenuhi, sehingga pengujian tidak dapat lanjut ke pengujian ANOVA. Hal ini menjadi keterbatasan penelitian karena data memiliki varians kelompok yang berbeda, sehingga tidak dapat dilakukan pengujian perbedaan persepsi bimbingan akademik berdasarkan intensitas waktu bimbingan akademik. Untuk variabel intensitas waktu bimbingan, perlu dilakukan penelitian lebih lanjut dikarenakan berdasarkan hasil penelitian Young-Jones et al. (2013), intensitas waktu bimbingan akademik memiliki pengaruh terhadap tingkat 
kesuksesan akademik. Hasil penelitian Young-Jones et al. (2013) menunjukkan bahwa bimbingan akademik sangat berdampak pada kinerja akademik. Pertemuan dan bimbingan penasihat akademik pada siswanya berdampak pada tanggung jawab, keterampilan dan ketekunan belajar, serta dukungan moral siswa dalam menghadapi proses pembelajaran. Hal ini menunjukkan bahwa intensitas waktu bimbingan antara penasihat dengan siswa berdampak pada kinerja akademik siswa.

\subsection{Perbedaan persepsi bimbingan akademik berdasarkan frekuensi bimbingan akademik dalam satu semester}

Kategori frekuensi bimbingan akademik dalam satu semester dibagi menjadi empat kategori, yaitu satu kali, dua kali, tiga kali, dan empat kali bimbingan akademik dalam satu semester. Dari 302 orang responden, mayoritas mengikuti bimbingan akademik dalam satu semester sebanyak dua kali (sebanyak 52,98\%), lalu sebanyak 24,83\% responden mengikuti bimbingan akademik sebanyak tiga kali dalam satu semester, dan sebanyak 13,58\% mengikuti bimbingan akademik sebanyak empat kali, dan sisanya hanya mengikuti bimbingan akademik sebanyak satu kali dalam satu semester. Pengujian perbedaan persepsi mahasiswa terhadap bimbingan akademik berdasarkan frekuensi perwalian selama satu semester memiliki lebih dari dua kategori, sehingga diuji dengan Anova test. Untuk memenuhi asumsi Anova, maka dilakukan uji varians terlebih dahulu dengan menggunakan test homogeneity of variances. Tabel 15 berikut adalah hasil uji varians dari variabel frekuensi bimbingan akademik dalam satu semester.

Tabel 15. Hasil uji varians variabel frekuensi bimbingan akademik dalam satu semester

\begin{tabular}{cccc}
\hline \multicolumn{4}{c}{ Test of homogeneity of variances } \\
\hline $\begin{array}{c}\text { Persepsi } \\
\text { Levene Statistic }\end{array}$ & df1 & df2 & Sig. \\
\hline 1,424 & 4 & 297 & 0,226 \\
\hline
\end{tabular}

Sumber: Hasil pengolahan SPSS (2020)

Nilai sig. menunjukkan angka 0,226, lebih besar dari alpha yang digunakan sebesar 0,05. Dapat disimpulkan bahwa varians kelompok penelitian memiliki varian yang sama dan asumsi Anova terpenuhi, sehingga dapat dlakukan pengujian Anova. Hasil pengujian perbedaan persepsi dengan uji Anova dapat dilihat pada Tabel 16.

Tabel 16. Hasil uji beda anova berdasarkan frekuensi bimbingan akademik dalam satu semester

\begin{tabular}{lccccc}
\hline Persepsi & \multicolumn{5}{c}{ ANOVA } \\
\hline & Sum of Squares & df & Mean Square & F & Sig. \\
\hline Between Groups & 24,486 & 4 & 6,121 & 2,469 & 0,045 \\
Within Groups & 736,424 & 297 & 2,480 & & \\
Total & 760,910 & 301 & & & \\
\hline
\end{tabular}

Sumber: Hasil pengolahan SPSS (2020)

Hasil uji anova menunjukkan terdapat perbedaan persepsi bimbingan akademik berdasarkan frekuensi bimbingan akademik dalam satu semester, hipotesis penelitian $\left(\mathrm{H}_{6}\right)$ diterima. Hal ini ditunjukkan oleh nilai sig. sebesar 0,045, lebih kecil dari alpha yang digunakan sebesar 0,05. Karena hasil uji Anova menunjukkan adanya perbedaan, maka pengujian selanjutnya adalah post hoc untuk melihat kelompok kategori frekuensi bimbingan akademik yang terdapat perbedaan persepsi bimbingan akademik.

Tabel 17. Hasil uji post hoc test berdasarkan frekuensi bimbingan akademik dalam satu semester

Dependent Variable: Persepsi

\section{Multiple comparisons}

Tukey HSD

(I)

(J)

J)

\begin{tabular}{ccccccc}
\hline (I) & $(\mathrm{J})$ & Mean & Std. & Sig. & \multicolumn{2}{c}{ 95\% Confidence Interval } \\
\cline { 4 - 6 } $\begin{array}{c}\text { Frekuensi_Satu } \\
\text { _Semester }\end{array}$ & $\begin{array}{c}\text { Frekuensi_Satu } \\
\text { _Semester }\end{array}$ & $\begin{array}{c}\text { Difference } \\
\text { (I-J) }\end{array}$ & Error & & Lower & Upper \\
Bound & Bound \\
\hline
\end{tabular}

Sig.

\begin{tabular}{|c|c|c|c|c|c|c|}
\hline (I) & (J) & Mean & Std. & \multirow[t]{2}{*}{ Sig. } & \multicolumn{2}{|c|}{$95 \%$ Confidence Interval } \\
\hline $\begin{array}{c}\text { Frekuensi_Satu } \\
\text { _Semester }\end{array}$ & $\begin{array}{c}\text { Frekuensi_Satu } \\
\text { _Semester }\end{array}$ & $\begin{array}{l}\text { Difference } \\
(\mathrm{I}-\mathrm{J})\end{array}$ & Error & & $\begin{array}{l}\text { Lower } \\
\text { Bound }\end{array}$ & $\begin{array}{l}\text { Upper } \\
\text { Bound }\end{array}$ \\
\hline
\end{tabular}


Jurnal Manajemen Maranatha — Vol. 20 Nomor 2, Mei (2021)

\begin{tabular}{ccccccc}
\hline \multirow{3}{*}{1 kali } & 2 kali & 0,22724 & 0,34469 & 0,965 & $-0,188$ & 1,1733 \\
& 3 kali & $-0,33372$ & 0,36929 & 0,895 & $-1,3473$ & 0,6798 \\
& 4 kali & $-0,44239$ & 0,40471 & 0,810 & $-1,5532$ & 0,6684 \\
\multirow{3}{*}{2 kali } & 4 kali & 0,00321 & 1,15892 & 1,000 & $-3,1776$ & 3,1840 \\
\hline \multirow{3}{*}{3 kali } & 1 kali & $-0,22724$ & 0,34469 & 0,965 & $-1,1733$ & 0,7188 \\
& 3 kali & $-0,56096$ & 0,22036 & 0,084 & $-1,1658$ & 0,0438 \\
& 4 kali & $-0,66963$ & 0,27563 & 0,110 & $-1,4261$ & 0,0869 \\
& $>4$ kali & $-0,22404$ & 1,12039 & 1,000 & $-3,2991$ & 2,8510 \\
\hline \multirow{3}{*}{4 kali } & 1 kali & 0,33372 & 0,36929 & 0,895 & $-0,6798$ & 1,3473 \\
& 2 kali & 0,56096 & 0,22036 & 0,084 & $-0,0438$ & 1,1658 \\
& 4 kali & $-0,10867$ & 0,30584 & 0,997 & $-0,9481$ & 0,7307 \\
& $>4$ kali & 0,33692 & 1,12820 & 0,998 & $-2,7595$ & 3,4334 \\
\hline \multirow{3}{*}{4 kali } & 1 kali & 0,44239 & 0,40471 & 0,810 & $-0,6684$ & 1,5532 \\
& 2 kali & 0,66963 & 0,27563 & 0,110 & $-0,0869$ & 1,4261 \\
& 3 kali & 0,10867 & 0,30584 & 0,997 & $-0,7307$ & 0,9481 \\
& 4 kali & 0,44559 & 1,14028 & 0,995 & $-2,6840$ & 3,5752 \\
\hline Suli & $-0,00321$ & 1,15892 & 1,000 & $-3,1840$ & 3,1776 \\
& 2 kali & 0,22404 & 1,12039 & 1,000 & $-2,8510$ & 3,2991 \\
& 3 kali & $-0,33692$ & 1,12820 & 0,998 & $-3,4334$ & 2,7595 \\
& 4 kali & $-0,44559$ & 1,14028 & 0,995 & $-3,5752$ & 2,6840 \\
\hline
\end{tabular}

Sumber: Hasil pengolahan SPSS (2020)

Pengujian post hoc test dengan melihat tabel multiple comparison pada Tabel 17 untuk menentukan apakah kelompok-kelompok kategori memiliki perbedaan atau tidak. Responden yang melakukan bimbingan akademik sebanyak satu kali dengan yang dua kali memiliki nilai sig. 0,965 dan nilai tersebut lebih besar dari alpha 0,05, maka dapat disimpulkan bahwa persepsi bimbingan akademik berdasarkan frekuensi satu kali dengan yang dua kali dalam satu semester tidak terdapat perbedaan. Demikian pula hasil perbandingan perbedaan antar frekuensi bimbingan akademik kategori lainnya memiliki nilai sig. lebih besar dari alpha, sehingga disimpulkan tidak terdapat perbedaan persepsi bimbingan akademik berdasarkan frekuensi tiap kategorinya.

Hal ini menjadi menarik ketika melihat hasil uji Anova menunjukkan terdapat perbedaan persepsi bimbingan akademik berdasarkan frekuensi bimbingan akademik selama satu tahun, namun tidak terlihat perbedaan antar kategorinya. Ada indikasi yang memperlihatkan bahwa proses bimbingan akademik yang dilakukan hanya terbatas ketika ada jadwal formal untuk melakukan bimbingan akademik dari fakultas. Temuan terdapat perbedaan persepsi berdasarkan frekuensi bimbingan akademik dalam satu semester ini menguatkan hasil penelitian terdahulu yang mengatakan bahwa semakin sering bimbingan akademik dilakukan, semakin baik relasi yang terbangun antara mahasiswa dan dosen wali, serta akan meningkatkan capaian akademik mahasiswa (Walker et al., 2017). Frekuensi bimbingan erat kaitannya dengan intensitas pemberian infomasi, aksesibilitas pembimbing, hubungan dua arah, serta saluran dan konten komunikasi. Walker et al. (2017) juga membingkai faktor kepuasan mahasiswa dengan proses pemberian nasehat akademik, dikaitkan dengan frekuensi bimbingan yang dilakukan pembimbing dan mahasiswa.

\section{SIMPULAN DAN SARAN}

Bimbingan akademik sangat penting untuk dipahami oleh pengelola fakultas dan program studi dalam mengintervensi perkembangan akademik dan personal mahasiswa. Gaya bimbingan akademik yang sudah terbentuk pada responden penelitian adalah gaya bimbingan akademik developmental. Pada penelitian terdahulu tahun 2020, skor gaya bimbingan akademik yang didapat adalah 68,83 dengan standar deviasi 20,67, yang mana skor bimbingan akademik developmental berada pada rentang 53104. Hasil uji perbedaan persepsi bimbingan akademik pada penelitian lanjutan memperlihatkan hasil yang menarik untuk dijadikan dasar perbaikan sistem bimbingan akademik pada program studi sarjana manajemen di suatu perguruan tinggi swasta ini. 
Perbedaan persepsi bimbingan akademik terlihat berdasarkan variabel usia, angkatan kuliah, dan frekuensi bimbingan akademik dalam satu tahun. Kategori usia dibagi menjadi dua, yang mana kategori pertama merupakan kategori usia mahasiswa memasuki tahun pertama sampai ketiga pada umumnya dan kategori usia kedua adalah kategori usia mahasiswa memasuki tahun terakhir perkuliahan pada umumnya. Perbedaan persepsi bimbingan akademik terjadi pada variabel usia memberikan masukkan bahwa diperlukan desain bimbingan akademik secara khusus bagi mahasiswa baru pada awal-awal semester. Demikian pula dengan perbedaan persepsi bimbingan akademik berdasarkan angkatan kuliah. Mahasiswa angkatan baru dan angkatan lama mengalami perbedaan persepsi bimbingan akademik. Desain bimbingan akademik bagi angkatan kuliah yang awal perlu disiapkan dengan lebih terstruktur agar seluruh informasi awal tentang proses perkuliahan dapat diterima dengan baik oleh mahasiswa baru. Sementara, ada indikasi bagi mahasiswa angkatan atas, bentuk bimbingan akademik diarahkan pada desain sesi konseling yang menekankan pada persiapan karir setelah lulus kuliah.

Tidak adanya perbedaan persepsi bimbingan akademik berdasarkan variabel gender dan asal daerah tempat tinggal mengindikasikan bahwa proses bimbingan akademik berjalan secara objektif, tidak ada faktor pembeda berdasarkan apakah mahasiswa bimbingan laki-laki atau perempuan atau asal daerah tempat tinggal mahasiswa yang berasal dari dalam kota Bandung, luar kota Bandung, bahkan luar pulau Jawa. Hasil penelitian membuktikan bahwa tidak terdapat perbedaan persepsi bimbingan akademik berdasarkan gender dan asal daerah tempat tinggal. Kenyataan ini dapat menjadi masukkan bagi pengelola fakultas dan program studi bahwa pembagian mahasiswa wali dapat dilakukan tanpa mempertimbangkan variabel gender dan asal daerah tempat tinggal.

Adapun rekomendasi dan saran untuk penelitian selanjutnya adalah menggali faktor-faktor pembeda persepsi bimbingan akademik secara kualitatif dengan melihat kasus-kasus yang seringkali muncul dalam bimbingan akademik. Variabel intensitas waktu bimbingan akademik perlu dilakukan penelitian lebih dalam karena hasil penelitian belum dapat diketahui apakah terdapat perbedaan persepsi bimbingan akademik atau tidak. Kategori variabel intensitas waktu bimbingan akademik perlu ditinjau ulang pada penelitian selanjutnya, sekaligus dilakukan penelitian kualitatif secara khusus mengenai variabel ini. Penelitian ini juga dapat dilakukan pada tingkat pasca sarjana guna melihat gaya bimbingan akademik yang terjadi serta perbedaan persepsi mahasiswa guna mendukung capaian akademik mahasiswa tingkat pasca sarjana.

\section{ACKNOWLEDGEMENTS}

Penelitian ini sepenuhnya didukung oleh Universitas Kristen Marnatha secara materiil dan nonmateriil. Peneliti mengucapkan terima kasih yang sebesarnya kepada para responden yang bersedia meluangkan dan mengungkapkan gaya bimbingan akademik yang selama ini dialaminya. Terima kasih juga kepada program studi sarjana manajemen yang telah mengijinkan penelitian ini dijalankan sehingga memberikan gambaran penyempurnaan sistem perwalian (bimbingan akademik) di Program Studi S1 Manajemen UKM. Serta ucapan terima kasih sebesar-besarnya disampaikan kepada Beta Solution sebagai lembaga konsultasi statistika di Fakultas Ekonomi UK. Maranatha, terutama kepada Siereen Kasturi sebagai koordinator pengolahan data. Tim penulis juga mengucapkan terima kasih kepada para reviewer yang memberikan pandangan dan komentar atas hasil review artikel ini.

\section{REFERENSI}

Al-Omari, A. A., \& Khasawneh, S. A. (2014). Academic advising styles as perceived by undergraduate students in the Hashemite University. University Journal of Educational Sciences, 9(1), 125-140. doi.org/10.12816/0015535

Ayon, N. S. (2015). Academic advising: Perceptions of students in a Lebanese University. International E-Journal of Advances in Education, 1(2), 119-126. doi.org/10.18768/ijaedu.26010

Crookston, B. B. (1994). A developmental view of academic advisement as teaching. NACADA Journal, 2(14), 5-9. doi.org/10.12930/0271-9517-14.2.5 
Enduljee, N. B., \& Michaud, R. G. (2014). Student perceptions and levels of satisfaction about academic advising. International Journal of Psychosocial Research, 3(1), 1-13. https://www.researchgate.net/publication/270759373

Ghozali, I. (2013). Aplikasi analisis multivariate dengan program SPSS. Badan Penerbit Universitas Dipenogoro

Gordon, V. N., \& Hebley, W. R. (2000). Academic advising: A comprehensive handbook. Jossey Bass Higher and Adult Education Series

Harris, T. A. (2018). Prescriptive vs developmental: Academic advising at a historically black University in South Carolina. NACADA Journal, 1(38), 36-26. doi.org/10.12930/nacada-15-010

Hsu, M., \& Bailey, A. (2011). Retention in business education: Understanding business student perceptions of academic advising and college life. International Journal of Business and Social Science, 2 (21), 33-41. http://ijbssnet.com/journals/Vol_2_No_21_Special_Issue_November_2011/ 5.pdf

Junita, I., Limijaya, S., \& Kristine, F. (2020). A study of undergraduate students' perception about academic advising in an Indonesian university. Journal Humaniora, 11(2), 129-135. doi.org/10.21512/humaniora.v11i2.6490

Kato, T., \& Song, Y. (2018). An advisor like me: Does gender matter?. IZA Discussion Paper No. 11575. https://ssrn.com/absract=3193329

Lowenstein, M. (1999). An alternative to the development theory of advising. The Mentor: An Academic Advising Journal, 1. https://journals.psu.edu/mentor/article/view/61758/61402

Roessger, K. M., Eisentrout, K., \& Hevel, M. S. (2019). Age and academic advising in community colleges: Examining the assumption of self-directed learning. Community College Journal of Research and Practice, 43(6), 441-454. https://doi.org/ 10.1080/10668926.2018.1490669

Schwitzer, A. M., Griffin, O. T., Ancis, J. R., \& Thomas, C. R. (1999). Social adjustment experiences of African-American college students. Journal of Counseling and Development, 77(2), 189-197. doi.org/10.1002/j.1556-6676.1999.tb02439.x

Sekaran, U., \& Bougie, R. (2016). Research methods for business. John Wiley \& Sons

Soria, K. M. (2012). Advising satisfaction: Implications for first year students' sense of belonging and student retention. The Mentor: And Academic Advising Journal, 14. https://journals.psu.edu/mentor/article/view/61316/60948

Tobi-David, R., Adekeye, O., \& Odukoya, J. (2018). Comparative study of academic advising practise in public and private universities in Nigeria. ICERI 2018 Conference, 2536-2546. doi.org/10.21125/iceri.2018.1561

Walker, R. V., Zelin, A. I., Behrman, C., \& Strnad, R. (2017). Qualitative analysis of student perceptions: "Some advisors care. Some don't.'. NACADA Journal, 37(2), 44-54. doi.org/ 10.12930/nacada-15-027

Ward, P., Clark, T., Zabriskie, R., \& Morris, T. (2012). Paper/ pencil versus online data collection: An exploratory study. Journal of Leisure Research, 44(4), 507-530. doi.org/10.1080/00222216.2012.11950276

Winston, R. B. (1984). Academic advising inventory. GA: Student Development Associates

Winston, R. T., \& Sandor, J. A. (2002). Evaluating academic advising: Manual for the academic advising inventory. The University of Georgia

Young-Jones, A., Tracie, D. B., Stephanie, D., \& Melissa, J. H. (2013). Academic advising: does it really impact student success?. Quality Assurance in Education, 21(1), 7-19. https://eric.ed.gov/?id=EJ1004439 
Jurnal Manajemen Maranatha — Vol. 20 Nomor 2, Mei (2021) 